\title{
Fotografia e propaganda nas práticas de ensino em aulas de Geografia
}

\section{Fotografía y propaganda en las prácticas de enseñanza en clases de Geografía}

\begin{abstract}
Resumo:
O artigo traz reflexões sobre a importância do uso de imagens no processo de ensinoaprendizagem de Geografia. A fotografia e a propaganda, com seus inúmeros encantos, significados ou simulacros, abrem um universo de assuntos geográficos com possibilidade de serem trabalhados e relacionados ao dia a dia do professor e dos alunos. No artigo, as imagens usadas são fragmentos do contexto histórico-geográfico do Oeste do Paraná, em especial do município de Marechal Cândido Rondon, da década de 1950. As ações e as práticas de uso dessas fotografias e propagandas se desenvolveram durante as aulas da disciplina de Estágio Supervisionado III (Prática de Ensino em Geografia III), do Curso de Geografia, da Universidade Estadual do Oeste do Paraná (Unioeste), em 2013. A partir dos conhecimentos prévios dos alunos e do meio geográfico no qual eles estão inseridos (município e Oeste do Paraná) foi possível alcançar uma aprendizagem significativa e transitar por conteúdos aplicáveis ao ensino médio. As linguagens (fotografia e propaganda) serviram como apoio para as aulas, potencializando a análise e o conhecimento do espaço geográfico relativo aos conceitos e aos eixos temáticos do ensino médio onde o 'Estágio Supervisionado' é aplicado.
\end{abstract}

\section{Resumen:}

Este artículo reflexiona sobre la importancia del uso de imágenes en el proceso de enseñanza-aprendizaje de Geografía. La fotografía y la publicidad, con sus numerosos encantos, significados y simulacros, abren un universo de posibilidades geográficas a ser trabajadas y relacionadas al día a día del profesor y alumnos. Las imágenes usadas son fragmentos del contexto histórico-geográfico del Oeste de Paraná, en especial del Municipio de Marechal Cândido Rondon, década de 1950. Las acciones y prácticas se desarrollaran durante las clases de la disciplina de 'Estágio Supervisionado III' (Práctica de Enseñanza en Geografía III), del curso de Geografía, de la Universidade do Oeste do Paraná (Unioeste), en 2013. A partir de los conocimientos previos de los alumnos y del medio geográfico en el que ellos están inseridos (municipio y Oeste de Paraná), se ha logrado un aprendizaje significativo y pasado por contenidos aplicables a la enseñanza secundaria. Los lenguajes funcionaran como apoyo para las clases de la disciplina y potencializaran el análisis y el conocimiento del espacio geográfico, relacionados a los conceptos y referencias temáticas de la enseñanza secundaria de Geografía, donde la 'Práctica Supervisada' es aplicada.
Lia Dorotéa Pfluck*

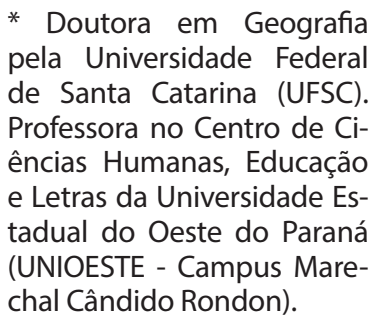

chal Cândido Rondon).
Palavras-chave:

ensino de Geografia, fotografia, propaganda, práticas de ensino

Key-Words:

enseñanza de geografía, fotografía, publicidad, prácticas de enseñanza 


\section{INTRODUÇÃO}

$\mathrm{D}$ esde as pinturas rupestres da pré-história as pessoas utilizam imagens para se comunicar de uma forma mais sofisticada do que o cotidiano imediato. Tanto as pinturas quanto as imagens (corporais eu em paredes de pedra) desses povos primitivos, passando pela arte pictórica dos séculos posteriores, em telas ou paredes de templos ou palácios, ou incluindo fotografias (a partir do século XIX) e a sua utilização nas atividades religiosas, políticas ou de propaganda comercial, mostram fragmentos congelados de espaços de tempo e não se esgotam por si mesmas.

A fotografia e a propaganda (figuras) são registros de mensagens que se elaboram através do tempo, tanto como documentos, quanto como testemunhos diretos do passado. $E$, em razão da facilidade de obtenção e de manuseio dessas figuras, podem suscitar-se diferentes leituras e interpretações, servindo como instrumentos de apoio à pesquisa e como ferramentas de auxílio no ensino escolar de geografia. É essa ideia que se pretende discutir aqui, com o objetivo de apresentar questões teóricas sobre essas e a sua relação com o conhecimento e com o ensino escolar de geografia. Além dessa discussão, também são apresentadas ações, práticas e possibilidades de seu uso para o ensino de geografia a partir da preparação de aulas relacionando as imagens com um conteúdo de ensino médio. As imagens foram levadas à sala de aula do $4^{\circ}$ ano do curso de Geografia, nas aulas de 'Prática de Ensino de Geografia III' (Estágio Supervisionado III), de 2013. Nas aulas de prática de ensino, as imagens e outros recursos ${ }^{1}$ foram distribuídos por meio de sorteio aos acadêmicos, estes organizados em grupos de dois a quatro.

Para este artigo, foram destacadas duas fotografias e um fragmento de propaganda, parte do contexto histórico-geográfico do oeste do Paraná, do município de Marechal Cândido Rondon, da década de 1950, e podem ser trabalhadas de forma independente ou inter-relacionadas. As fotografias retratam um mesmo pé de mandioca em duas situações diferentes, enquanto planta e o resultado da colheita, as suas raízes. $O$ 'folheto de propaganda elaborado pela Maripá2, no final da década de 1940, sobre as características físicas do oeste do Paraná, distribuídos a agricultores do Rio Grande do Sul e de Santa Catarina desejosos de comprar mais e meIhores terras. A propaganda atende, igualmente, aos interesses da colonizadora Maripá, vender terras, comprovar a produtividade da mesma com as fotografias.

\section{FOTOGRAFIA E PROPAGANDA: QUESTÕES TEÓRICAS}

A fotografia e a propaganda, com seus inúmeros significados e leituras, podem abrir ao professor de Geografia um universo de possibilidades didático-pedagógicas. Trata-se de meios a serem trabalhados e relacionados ao cotidiano escolar, de forma tornar o processo de ensino-aprendizagem mais atraente e prazeroso tanto ao professor quanto aos alunos. Trabalhar imagem requer domínio da técnica e domínio do conteúdo, daí que não se trata de recurso didático simplório, mas sim desafiador.

Para Barthes (1978), a fotografia opera em três estágios interdependentes: uma conotação meramente perceptiva; uma visada de natureza cognitiva, em que a leitura da imagem depende da cultura e do conhecimento do receptor; e percepção ideológica, em que, na leitura da imagem, o receptor introduz razões e valores.

A fotografia, segundo Kossoy (1989, p. 14), é “[...] uma das invenções que [...] teria papel fundamental enquanto possibilidade inovadora de informação e conhecimento, instrumento de apoio à pesquisa nos diferentes campos da ciência [...]". Com a multiplicação das imagens fotográficas, iniciou-se um novo processo de conhecimento em um mundo fragmentado em termos visuais, de recordação e de autoconhecimento, de documentação e de denúncia e, por que não, uma arma passível de toda a sorte de manipulação (KOSSOY, 1989).

Para Gavin (1985 apud KOSSOY, 1989, p. 18), "[...] os documentos fotográficos, apesar de sua legendária superioridade em relação aos registros verbais, ainda hoje escapam da malha fina da erudição". Tanto professores como alunos, habituados a somente ler palavras, tornam-se "[...] analfabetos para a leitura de imagens, dos sons" (KENSKI, 1996, p. 132), enquanto aprender a ler, a interpretar e a 
analisar o que está "escrito" em uma imagem pode revelar o contato com outras formas de ler o mundo.

A fotografia é um testemunho "[...] válido, não importando se o registro fotográfico foi feito para documentar um fato ou representar um estilo de vida". Como imagem-documento, é "[...] marca de uma materialidade passada, na qual objetos, pessoas, lugares nos informam sobre determinados aspectos desse passado - condições de vida, moda, infraestrutura urbana ou rural, condições de trabaIho, etc." (MAUAD, 1996, p. 8). As fotografias levam a recordações e a saudades de um passado que não volta mais; fazem imaginar o que não se viveu; fazem viajar nas distâncias do pensamento; trazem questionamentos (PFLUCK, 2013).

Enquanto imagem-monumento, "[...] a fotografia é um símbolo, aquilo que, no passado, a sociedade estabeleceu como a única imagem a ser perenizada para o futuro" (MAUAD, 1996, p. 8). Mauad alerta também para o fato de que "[...] todo documento é monumento, se a fotografia informa, ela também conforma uma determinada visão de mundo." Além disso, "[...] o processo de produção, circulação e consumo das imagens fotográficas [...]" remete a um circuito social nos diferentes períodos de sua história (MAUAD, 1996, p. 8).

Por outro lado, "A Geografia, auxiliada [pela fotografia e] pela arte de fotografar pode nos indicar de que maneira podemos olhar a paisagem e levar [o professor e] o aluno a desbravar o mundo além da sala de aula" (TRAVASSOS, 2001, p. 1). Assim, a fotografia, de fácil obtenção e manuseio, torna-se "[...] uma poderosa ferramenta de auxílio no ensino de Geografia [...]. Com ela, podemos trabalhar temas e conceitos importantíssimos para a nossa disciplina, como a paisagem, o território e o espaço geográfico - e suas dinâmicas" (SANTOS e CHIAPETI, 2011, p. 169).

E, como documento voltado ao oeste paranaense (que é o caso aqui), a imagem fotográfica e a propaganda constituem um reforço, um elemento palpável e visual a mais, ainda que passível de manipulação, para desencadear a organização espacial econômica do Oeste do Paraná desde a década de 1940. Ou seja:"Para atrair os colonizadores de antigas colônias alemãs, italianas, polonesas ou outras do Rio Grande do Sul, de Santa Catarina, de São Paulo, principalmente, muita propaganda foi feita através de fo-
Ihetos e de fotografias" (PFLUCK, 2013, p. 96).

Além da mensagem oral ou escrita, "[...] a fotografia na imprensa escrita exerce um importante papel na construção da mensagem [...]", o que equivale a dizer que a fotografia incrementa a credibilidade do texto escrito. (LEÃO e LEÃO, 2008, p. 31). Por outro lado, uma fotografia também pode facilitar a manipulação da realidade perante os leitores, pois não aparece o que pode estar por trás da imagem registrada, na organização do cenário, o não perceptível para os que não estiverem no momento do registro. A propaganda, o folheto e a fotografia, no caso, foi um modo de comunicação, uma forma clara e simples de transmitir a ideia a ser divulgada: "[...] uma difusão e uma divulgação de ideias, valores, opiniões, informações para o maior número de pessoas no mais amplo território possível". E, ainda, "[...] as artes gráficas, a fotografia [...] difundindo-se por meio de jornais, revistas, cartazes, rádio [...] a propaganda comercial [...] é a difusão e divulgação de produtos destinados à venda e dirigida a consumidores" (CHAUÍ, 2006, p. 37-38). A propaganda, para ser eficaz, deve afirmar que o produto possui valores estabelecidos pela sociedade e precisa despertar desejos no consumidor, conforme Chauí (2006). O produto à venda, no Oeste do Paraná, era a terra parcelada e comercializada pela Maripá. O consumidor - o colono, o agricultor - é o imigrante, principalmente o sulista, que se instala no município a partir de 1950, em busca de terra boa e acessível, para nela produzir na perspectiva de um futuro melhor para a família. E é bem essa a expectativa transmitida pela propaganda: "O maior desejo de cada agricultor é: que seu filho deve ter uma vida melhor"(Figura1). Além dessa perspectiva, outro fator que despertou desejos estava relacionado à compra de uma terra legal, com todas as garantias, com escritura pública ${ }^{3}$.

Ainda, segundo Chauí (2006), se a vida familiar era valorizada, o produto deveria aparecer a serviço dos pais e dos filhos. Nesse caso, a Maripá dispunha a terra em condições desejáveis para proporcionar um futuro melhor para o filho do agricultor e, consequentemente, para a família.

Para serem alcançadas essas expectativas, a propaganda enfatizava as "qualidades geográficas" encontradas nas terras da Fazenda da Maripá, e apontava 


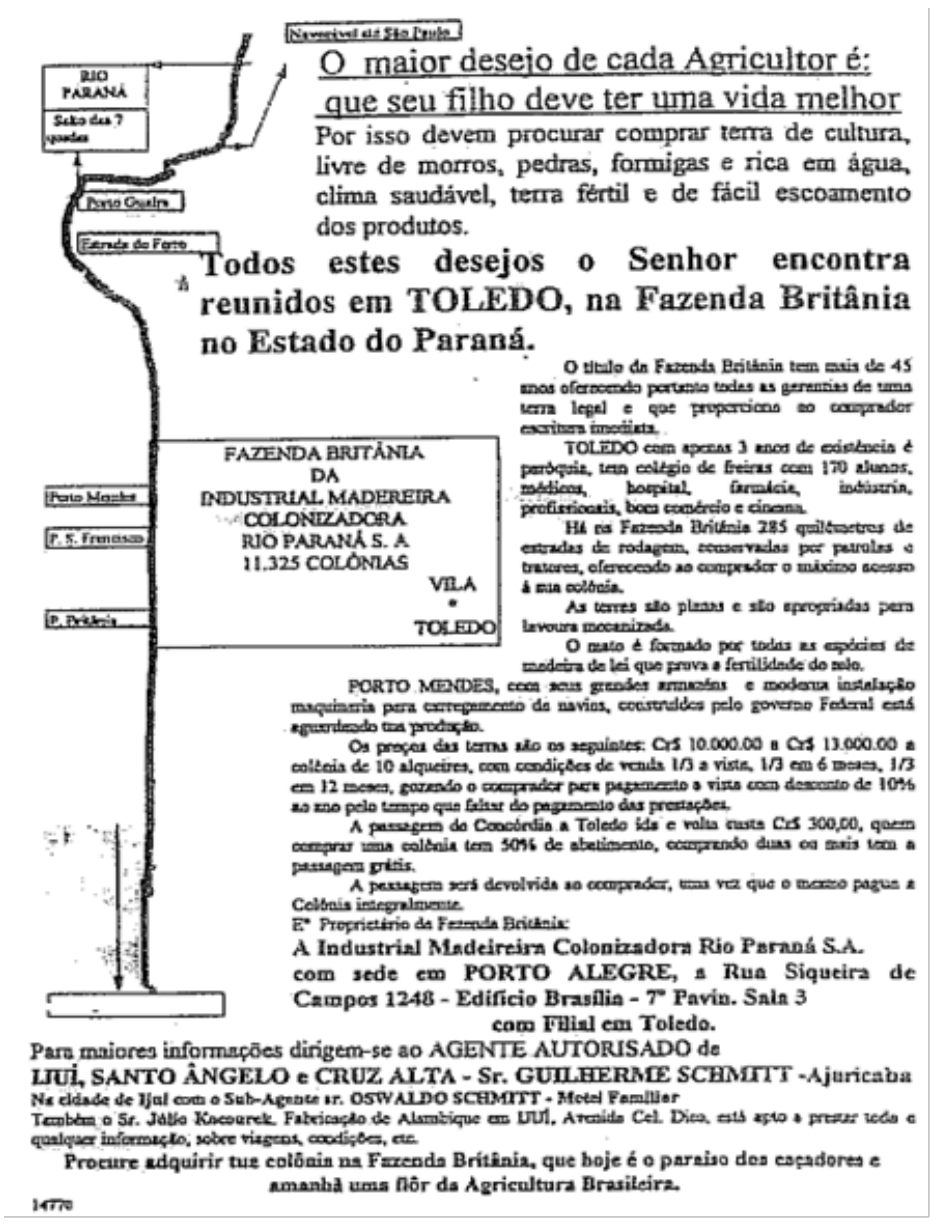

Figura 1: Folheto de Propaganda da Maripá.

Fonte: material de propaganda elaborado pela companhia Maripá e distribuído no Rio Grande do Sul.

uma infraestrutura para o escoamento da produção, o que, consequentemente, poderia significar um retorno econômico. O folheto iniciava com a frase "Todos estes desejos o Senhor encontra reunidos em TOLEDO, na Fazenda Britânia no estado do Paraná". E, em seguida, discorria sobre os fatores naturais ou humanizados que poderiam ajudar na realização desses desejos, isto é, "[...] terra de cultura livre de morros, pedras e formigas e rica em água, clima saudável, terra fértil e de fácil escoamento dos produtos" (Figura1).

Ofolheto traz temas, mesmo sublimares, que podem ser explorados pela Geografia, tais como: (i) migração (das colônias tradicionais do Sul; do próprio Paraná com o avanço da frente agrícola; e paulista, relacionada ao movimento migratório nacional); (ii) aspectos econômicos (terra de cultura, terra fértil); e (iii) infraestrutura, que pressupõe a existência de estradas ou de caminhos fluviais, como o Rio Paraná e seus afluentes e quatro portos, e, ainda, uma ferrovia apontadas no folheto (a facilitar o escoamento da produção). Fatores que poderiam atrair o imigrante, aliados ao seu bem -estar (terra rica em água, clima saudável) e à produção agrícola (sem morros, sem pedras e sem formigas, clima saudável, terra fértil e região de fácil escoamento de produtos).

A mensagem, de compreensão acessível e influenciável, foi propagada nas áreas de emigração, no entanto isso não significaria que o propagado e confirmado pela fotografia fosse o encontrado. Por um lado, era necessário superar "[...] a angústia, o medo, a resistência e os ressentimentos do momento da mudança, o olhar para trás [...]" (LUCENA, 1998, p. 82-83) e, por outro, na 'terra dos sonhos' encontraram dificuldades em relação à mata fechada, aos insetos, aos animais selvagens, à falta de estradas e de meios de transporte, à falta de alimentos, entre outras deficiências.

A fotografia e a propaganda, que acompanham o cotidiano de professores e de alunos, são recursos di- 
dáticos que podem tornar o ensino de geografia mais atraente, dinâmico, prazeroso e, ao mesmo tempo, desafiador. Aqui se propõe trabalhar com esses recursos visando possibilitar a utilização adequada dos recursos encontrados nos livros didáticos. Sobre o uso e a importância da propaganda e da fotografia, Maccari (1999) apresenta, em sua dissertação, fragmentos de entrevistas, como:

[...] olha eles ${ }^{4}$ iam de casa em casa [...]. Não era propaganda na rádio, né. Eles falava e falava a verdade (...) Olha, era difícil alguém voltá sem comprá. Vinham do Rio Grande do Sul, [...] de tudo lugar veio (...) eles falava que podia plantá tudo como lá no sul, mais sem as formigas e as pedras e moros que nóis tinha lá. Mostrava fotografias das plantações de milho, mandioca, trigo e também falava que dava muito bem o café (M. B.). (p. 61-62, grifo nosso). A propaganda era assim, eles contaram como era aqui (...) [...] das plantações, que a terra era boa, o que a gente podia plantá, [...] as pessoas que vinha olhá também falava prá gente". (M. R.). (p. 72).

Essas dinâmicas, os atores das propagandas e seus discursos convincentes, faziam acreditar que "Eles falava e falava a verdade"(MACCARI, 1999). Sobre as fontes orais, Maccari (1999, p. 23) defende de que "Se a memória é socialmente construída, é óbvio que toda documentação também o é. [...] A crítica da fonte [...] deve [...] ser aplicada a fontes de todo tipo. [...] a fonte oral é exatamente comparável à fonte escrita". Por outro lado, "O estereótipo da propaganda pode alcançar o ponto máximo de irrealidade quando o produto é anunciado por atores interessados no negócio, [...]" (CHAUÍ, 2006, p. 8),neste caso, pelos empresários e corretores da Maripá. Ainda que o contexto ou conjunto dos registros seja composto por imagens fixas ou imutáveis, cada ícone desses é constituído de valores que podem moldar subjetividades. Segundo Tonini:

Ao entender que a imagem ensina uma visão de mundo, de valores e quais comportamentos sociais e econômicos são aceitáveis, percebo existir ali regime de verdades. A imagem, por possuir estoque de verdade, vai moldando, constituindo nossas subjetividades. Ela é precisamente um veículo dos significados e mensagens simbólicas. (TONINI, 2003, p. 36).

A produção e o uso de uma propaganda ou de uma fotografia é, visivelmente, apenas um pedaço de papel que traz mensagem acessível e facilmente influenciadora, o que gera uma expectativa de mudança de valores econômicos e sociais. A propaganda escrita, juntamente com a fotografia, passa de mensagem sim- bólica para significados verdadeiros. A fotografia, nesse caso, foi um documento produzido após a propaganda escrita, e veio a confirmar o discurso dessa mesma propaganda, ou seja, a terra fértil, rica em água, de clima saudável, sem formigas, e que produz em tamanho e quantidade uma produção agrícola não conhecida pelos colonos imigrantes. Ainda, conforme Chauí, a propaganda comercial

[...] opera por meio de: 1) explicações simplificadas e elogios exagerados sobre os produtos; 2 ) slogans curtos que possam ser facilmente memorizados; 3) aparente informação e prestação de serviço ao consumidor; 4) garantia de que o consumidor será, ao mesmo tempo, igual a todo o mundo. [...] O produto precisa despertar desejos. (CHAUÍ, 2006, p. 38).

Esses pontos foram abordados no folheto de propaganda da Maripá (Fig. 1). Por meio das propagandas também se exploraram as práticas agrícolas das famílias de colonos italianos, poloneses e alemães (sulistas) e de paulistas. Enquanto os sulistas precisavam de um pouco de frio para cultivar trigo, milho, etc., os paulistas queriam produzir café em terras sem geada. Essas práticas passam a se concretizar quando da aquisição de "[...] área de terras livres de morros, pedras e formigas [...]", com destaque à qualidade e às características físicas - terras ricas em água, solo fértil e clima saudável. Assim, ambas as frentes migratórias puderam vislumbrar o que desejavam: "[...] o maior desejo de cada agricultor é que seu filho deve ter uma vida melhor". Certamente, porém, a propaganda e as fotografias também foram utilizadas com toda sorte de manipulação. Mauad (1996, p. 2-3) questiona:

\begin{abstract}
Mas será a fotografia uma cópia fiel do mundo e de seus acontecimentos [...]? Por muito tempo esta marca inseparável de realidade foi atribuída à imagem fotográfica, sendo seu uso ampliado ao campo das mais diferentes ciências. [...] utilizada como prova infalsificável. [...] imagem fotográfica foi associada à identificação, passando a figurar, desde o início do século XX, em identidades, passaportes [...]. No âmbito privado, através do retrato de família, a fotografia também serviu de prova. [...] modo de vida e de uma riqueza perfeitamente representada através de objetos, poses e olhares. [...] é uma elaboração do vivido, o resultado de um ato de investimento de sentido, ou ainda uma leitura do real realizada.
\end{abstract}

Esse questionamento também se aplica ao processo de imigração e ocupação do Oeste do Paraná, ou seja, entre os fragmentos de entrevistas, um imigrante da década de 1950 assim expõe: 
Eu tenho uma história prá contá de um corretor [Roque]. [...] daí essa gente queria comprá terra prá plantá trigo e onde tem pinhal dá geada [Toledo], [...] veio alguns paulista, ali eles pedia terras prá planta café. Ele então levava prá Mercedes. Outra vez vinham os que queria plantá trigo, mas não queria as terras de Toledo. Ele levava prá Mercedes. [...] um dos compradores observou isso, e disse: Como é seu Roque, você falou que não gia [geada] e que dá café e pro pessoal de Santa Catarina você falou que gia (...). Depende prá que vocêis querem a terra: se é prá café não gia, se é prá trigo gia. (J. F.). (MACCARI, 1999, p. 63).

A propaganda feita de casa em casa, pela oralidade das pessoas que vinham olhar a terra da Maripá, pelo uso de fotografias e pela "produção" ou "adaptação" de características geográficas - conforme os interesses do corretor - são estratégias e dinâmicas vivas e documentais, isto é, uma arma passível de toda a sorte de manipulação (KOSSOY, 1989).

Quanto ao uso da propaganda e da fotografia, também se pode recorrer a Sánchez (1999, p. 80) quando ele considera que "A função dos meios é influenciar os receptores, e essa influência pode ser maior se o receptor não dispuser da totalidade das ferramentas para sua análise." É nesse contexto que o município de Marechal Cândido Rondon surge efetivamente a partir do projeto de colonização elaborado pela empresa privada Maripá, empresa instituída para dedicar-se à compra e à venda de terras, bem como à extração, industrialização e exportação de madeira.

A forma de conduzir o discurso e o relacionamento entre os migrantes, corretores e diretores da empresa colonizadora foi de fundamental importância para dirimir divergências e ou adversidades relacionadas também à infraestrutura básica sanadas em conjunto. Essa cooperação atendeu a interesses específicos, pois se, por um lado, a Maripá auxiliou aos migrantes, por outro, se beneficiou com a propaganda, o que, por sua vez, incentivou mais ainda a vinda de novos migrantes (MACCARI, 1999) e garantiu o sucesso do empreendimento imobiliário.

Assim, os imigrantes estabelecidos se tornaram fontes orais, fontes vivas de informação, serviram e foram servidos de verdades orais e visíveis, por imagens, confirmando o escrito na propaganda da Maripá, ainda que com o tempo pudessem ser vistos como irreais sob vários aspectos e o colonizador/consumidor não ter se tornado um "igual a todo o mundo" (CHAUÍ, 2006). Concorda-se com Mauad (1996, p. 3) quando afirma que, "[...] entre o sujeito que olha [ouve ou lê] e a imagem que elabora, há muito mais que os olhos podem ver" [os ouvidos podem ouvir e a boca pode ler e falar].

Assim, outra leitura geográfica se abre ao professor, diante de fotografias e de folhetos de propaganda, ao intentar uma análise acurada das causas que levaram à ocupação de um tido vazio demográfico em área de fronteira, no sertão do Paraná, uma fronteira agrícola. Segundo Maccari (1999, p. 156),

\begin{abstract}
Com a interiorização, o poder público objetivava solucionar uma série de problemas, [...] ocupar os espaços tidos como vazios demográficos, povoar as áreas de fronteira e estimular a agricultura de subsistência a partir da criação de núcleos coloniais agrícolas. [...], a pequena propriedade deveria criar as condições para o surgimento de uma camada social [como] mercado consumidor, [...] diversificação da economia, [...] comercialização do excedente [...] através da policultura e do uso da mão-de-obra familiar.
\end{abstract}

Ainda conforme Maccari (1999), a mão de obra excedente viria dos centros urbanos, dos antigos núcleos coloniais do Sul do país e da frente cafeeira paulista para o Oeste do Paraná. Para tanto, o poder público do Estado do Paraná estabeleceu"regras" e deu sustentáculo aos discursos do governo federal, como: facilidade e aceleração do processo de ocupação, parcelamento do pagamento das terras, planejamento de obras públicas (infraestrutura mínima para receber as famílias e dar suporte ao escoamento agrícola), escolha de migrantes ideais para o projeto (poder fiscalizador dos poderes público e privado), criação ou reformulação de órgãos de administração direta para divulgar as possibilidades econômicas locais e dar assistência aos migrantes. Moisés Lupion (Moysés Wille Lupion de Troya), governador do Estado do Paraná (19471950 e 1956-1960), apresentou, em seu discurso, o interesse de:

[...] atrair migrantes, localizá-los de acordo com suas meIhores possibilidades de adaptação, dar-lhes a oportunidade de trabalho, terras férteis e promissoras: esse é certamente um programa de trabalho que consulta os mais altos interesses públicos. (IPARDES, 1989, p. 31).

A adoção desse discurso, por parte do poder público estadual, determinou um tratamento distinto para os imigrantes (gaúchos, catarinenses, paulistas), ou seja, os que planejavam tornar a área adquirida produtiva eram bem recebidos, pois produziriam riquezas para o Estado; enquanto aqueles que se apossavam sem esses objetivos, 
esses eram rejeitados 5 . Isso era contrário, portanto, ao que a propaganda induzia, de que "O maior desejo de cada Agricultoré: que seu filho dever ter uma vida melhor. Por isso devem comprar terra de cultura [...]. Todos estes desejos o Senhor encontra reunidos em TOLEDO", ou seja, a "garantia de que o consumidor será, ao mesmo tempo, igual a todo o mundo"(CHAUÍ, 2006).

Em outro momento é possível mergulhar em questões sobre o interesse do governo estadual em administrar e conduzir a ocupação das terras do oeste do Paraná, de suas estratégias e dos seus parâmetros no direcionamento de migrantes $\nabla$ uma análise mais delongada dessas estratégias e desses parâmetros é, certamente, assunto para um estudo de outro teor e independente deste aqui. Da mesma forma, analisar as características físicas do oeste paranaense, comparando-as com as afirmações das propagandas feitas pelas empresas colonizadoras e pelo próprio governo da época propiciam novas análises,em outro momento.

Kossoy $(1989$, p. 20) já considerava que "[...] as imagens são documentos insubstituíveis cujo potencial deve ser explorado. [...] [mas] jamais deverão ser entendidos como meras ilustrações ao texto."Como argumenta Mussoi (2008), como meras ilustrações, as fotografias não terão caráter criador de conhecimentos Para Oliveira Jr. (2009, p. 10), as imagens dão visualidade aos lugares, sobre o espaço geográfico grafam pensamentos e, "Impregnados no visual, nos chegam também sentidos para estes lugares, maneiras de significá-los uns em relação aos outros, propondo-nos raciocínios e imaginações acerca de cada um deles e das relações que existem entre eles." Além disso, cada leitor fará a sua interpretação significativa ediferenciada de outros observadores, pois a riqueza das imagens está na capacidade "[...] de veicular conceitos, gerar reflexão e didatizar o conhecimento" (MARTINS, 2002, p. 137), "[...] mesmo a realidade registrada sendo fixa ou imutável" (ASARI et al., 2004, p. 180).

Assim, em relação ao conhecimento geográfico, cabe aos professores estabelecer relações de causa e consequência, ir além da percepção, "[...] as categorias de análise da Geografia devem se sobrepor à linguagem da mídia" (LEÃO e LEÃO, 2008, p. 40). Essas categorias devem se sobrepor para limitar
[...] o risco de tomar por verdadeiro o que é só aparência. [...]. A percepção é sempre um processo seletivo de apreensão. Se a realidade é apenas uma, cada pessoa a vê de forma diferenciada [...]. A percepção não é ainda o conhecimento, que depende de sua interpretação. (SANTOS, 1988, p. 62).

Dessa forma, o professor de Geografia que souber selecionar o que for levar à sala de aula, pode transformar propagandas e fotografias em um texto útil para o ensino de Geografia, pois saberá "[...] perceber na imagem o que está nas entrelinhas, assim como fazemos em relação aos textos" (KOSSOY, 1989, p. 79). Tal utilização, no entanto, é válida somente desde que esse seja o ponto de partida para uma reflexão em que o conhecimento geográfico seja a referência. $O$ professor precisa ter ciência da geografia que quer ensinar, pois, sem o espaço da ressignificação da linguagem midiática, a aula de geografia serve de aluguel para o discurso da mídia, configura-se assim um processo de desterritorialização da geografia.

Cabe, portanto, ao professor o papel de ser "[...] mediador entre o aluno e a informação recebida, promovendo o'pensar sobre' e desenvolvendo a capacidade do aluno contextualizar, estabelecer relações e conferir significado às informações" (PONTUSCHKA et al., 2007, p. 262). E, nesse caso, entra também o uso da fotografia e, como já escrevia Kossoy $(1989$, p. 20):

As fontes fotográficas são uma possibilidade de investigação e descoberta que promete frutos na medida em que se tentar sistematizar suas informações, estabelecer metodologias adequadas de pesquisa e análise para a decifração de seus conteúdos e, por consequência, da realidade que os originou.

Ainda segundo Mauad (1996, p. 12), a produção da imagem é um trabalho humano de comunicação que se pauta em códigos socialmente convencionais: "A fotografia comunica através de mensagens não verbais, cujo signo constitutivo é a imagem [...]". Para tanto é preciso atentar para alguns pontos, como: (i) a relação entre signo e imagem, a imagem como algo 'natural', inerente à própria natureza, e o signo como uma representação simbólica; (ii) a imagem fotográfica enquanto mensagem, estruturada a partir de escolha efetuada em um conjunto de escolhas então possíveis; (iii) a relação entre o plano do conteúdo e o plano 
da expressão, a relação dos elementos da fotografia com o contexto no qual se inserem, remetendo-se ao corte temático e temporal feitos; e (iv) a compreensão das opções técnicas e estéticas, que envolvem um aprendizado historicamente determinado e pleno de sentido social.

Nesse contexto, as fotografias usadas no presente artigo se enquadram quando a imagem é inerente à própria natureza, mas o signo é uma representação simbólica do que se quer destacar - a fartura da produção agrícola. Ao mesmo tempo, a imagem fotográfica é uma mensagem que resultou da escolha entre um conjunto de escolhas então possíveis, ou seja, os agentes da Maripá poderiam ter mostrado a paisagem da floresta, a paisagem sem morros, os rios de água cristalina, as instalações portuárias e férreas, pois esses elementos a propaganda trazia por escrito, mas optaram por mostrar recortes pontuais. $\mathrm{E}$, quanto ao plano do conteúdo e ao plano da expressão, considerou-se o corte temático e temporal pleno de sentido social, isto é, apresentar a possibilidade da concretização do sonho de ter um futuro melhor, conforme o exposto no folheto de propaganda (Fig. 1). Em relação aos planos e propósitos da empresa colonizadora (Maripá) e as estratégias utilizadas para convencer o imigrante, cabe muito bem a máxima da fotografia amadora do começo do século XX: You press the button, we do the rest- Você aperta o botão, nós fazemos o resto (MAUAD, 1996, p. 8).

A respeito do uso de imagens, Tonini (2003, p. 43) lembra que, das 200 páginas de um livro didático, "[...] 80\% contêm algum tipo de imagem (mapas, tabelas, fotografias)". E, assim, "o conhecimento geográfico registrado nas imagens dos livros está oficializado como saber [...] seria importante que no ambiente da sala [...] trabalhássemos com a riqueza e a complexidade das imagens na construção do conhecimento geográfico" (TONINI, 2003, p. 37).

Essa situação também justifica a opção de trabalhar na Prática de Ensino com imagens (fotografias e propaganda) para construir o conhecimento geográfico. Além do mais, "Trabalhar com imagem, seu impacto e sua influência na subjetividade é um desafio legítimo e sedutor: a imagem cruza fronteiras, especificidades e bairrismos" (TONINI, 2003, p. 43). De acordo com Soares (2001, p. 132), mudam os tempos, mudam as pessoas, e

\begin{abstract}
Trazendo para a sala de aula a questão dos semióforos e o motivo edênico [fotografia e propaganda] [...] fica uma profunda indagação: [...]. Enquanto providos de significação ou de valor simbólico, capazes de relacionar o visível e o invisível, seja no espaço ou no tempo e expostos à visibilidade aí realizando sua significação e existência -, respondem os semióforos ao verdadeiro ensino e à real aprendizagem da Geografia no cenário inicial do século XXI?
\end{abstract}

Diante do exposto, parte-se para o questionamento de por que não lançar mão de métodos diversificados para a apropriação do conhecimento pelos alunos, e, nesse caso, o recurso, a ferramenta pedagógica ou a linguagem é a imagem - as fotografias e a propaganda - com seus inúmeros significados, complexos, subjetivos, concretos, reais ou irreais. Esse recurso pode abrir ao professor um universo de possibilidades geográficas a serem trabaIhadas e relacionadas à vivência dele e a dos alunos, e assim tornar o ensino mais atraente e prazeroso. Trata-se de um desafio legítimo e sedutor, esse de levar a'pensar sobre' e desenvolver a capacidade do aluno em contextualizar, estabelecer relações e conferir significado às informações. Assim se trabalhou com a fotografia e a propaganda em sala nas aulas de 'Prática de Ensino em Geografia'.

\section{AÇÕES E REVELAÇÕES}

Registros de mensagens por meio de fotografias e propaganda serviram, no decorrer do tempo, tanto de testemunho direto do passado, quanto de imagem-documento. A imagem se torna instrumento de apoio à pesquisa e auxilia na prática do ensino de geografia pela facilidade de sua obtenção, de seu manuseio e de permitir diferentes leituras e interpretações. Além de elencar questões teóricas sobre a fotografia e a propaganda, sua relação com o conhecimento e ensino de geografia, apresentam-se ações, práticas e possibilidades de seu uso para o ensino de geografia.

A proposta desenvolvida em sala de aula resultou na preparação de aula-piloto, aula experimental relacionando o recurso das imagens com um conteúdo de ensino médio e sua apresentação em sala para os colegas. A aplicação a este nível se justifica pelo fato de os acadêmicos, do $4^{\circ}$ ano do 
curso de graduação em Geografia, se encontrarem na fase prática da disciplina Estágio Supervisionado III (Prática de Ensino em Geografia III), desenvolvida em colégios da rede pública estadual do município (ensino médio). Essa proposta foi precedida da leitura, primeiro, do texto: "A escola e o ensino de Geografia: elementos para uma discussão", de Sposito (1997), em que o autor reflete sobre o momento de desvalorização do papel do professor e da tendência ao "discurso único". Isso leva o autor a considerar que a educação e o processo de ensino-aprendizagem devam estar relacionados a práticas pedagógicas diferenciadas para dinamizar a produção do conhecimento geográfico. Depois foram lidos os textos: "A natureza da produção do conhecimento geográfico no ensino médio", deAguiar e Antonello (2007) e "Simulacro e Poder: uma análise da mídia", de Chauí (2006).

Chauí (2006) descreve como a mídia ajuda a formar o imaginário social e cultural, reforçando mitos e estruturas de poder. Analisa como os discursos da mídia perpassam por interesses sociais, econômicos, com patrocinadores que conhecem e seduzem o mercado e inculcam necessidades ao comprador. Ao mesmo tempo, a atenção se dispersa, enquanto a capacidade de agir, de interagir e de refletir é abstraída. As referências usadas seguem uma ordem lógica e didática e fazem com que se enxerguem com outros olhos as imagens propagandistas da Maripá. O quarto texto foi "Semióforos, motivo edênico e ensino de geografia", deSoares (2001). Nesse texto, a partir do conceito "semióforo" (no sentido de expor, trazer para frente) é possível trabalhar com fotografias e propagandas enquanto signos de poder utilizados pelo Estado e pela empresa colonizadora. E a expressão 'motivo edênico'(próprio do Éden, paradisíaco) remete às terras da Fazenda Maripá, férteis, sem formiga, sem pedra..., o maior desejo da cada agricultor. No texto quinto, "Fronteiras, migrações e imaginários", de Gregory (2011), o autor contempla os imaginários que se construíram junto aos fluxos migratórios para as terras da Maripá e os valores edênicos atribuídos a essas terras, onde o rural simbolizava o sagrado, motivo o qual, com a modernização agrícola, passa a ter o ambiente e os valores corroídos. Um sexto e último texto foi "Impactos e riscos ambientais numa terra prometida", de Pfluck (2011), em que, a partir da migração rural -urbana, com o uso de fotografias, se problematiza a questão ambiental com fundamento nas concepções da geografia, alertando para o risco relacionado à ocupação de áreas de voçorocas, de fundos de vale e de chuvas concentradas. Em livros didáticos, nas Orientações Curriculares para o Ensino MédioOCEM (2006) e nos Parâmetros Curriculares Nacionais - PCNs, os acadêmicos puderam buscar tema e conteúdo que pudessem ser trabalhados com as imagens deste artigo. Esses e outros autores, incorporados à pesquisa feita para formular o artigo, foram debatidos durante a disciplina de Estágio Supervisionado III (Prática de Ensino em Geografia III). O ensino médio, segundo Callai, corresponde a

[...] um momento da escolaridade em que o aluno pode adquirir uma cultura geral, uma visão do mundo e de suas formas de interpretação, que supere o senso comum e lhe sirva de ferramenta para seguir adiante na sua formação profissional. [...] e passagem para a universidade. (CALLAl, 1999, p. 64).

As disciplinas de estágio supervisionado de ensino devem ser entendidas à luz do Parecer $n^{\circ}$ 28/2001, do Conselho Nacional de Educação - CNE (BRASIL, 2001, p. 10), ou seja,

[...] como um tempo de aprendizagem que, [...], alguém se demora em algum lugar do ofício para aprender a prática do mesmo e depois poder exercer uma profissão ou ofício. [...] uma relação pedagógica entre alguém que já é um profissional reconhecido em um ambiente institucional de trabalho e um aluno estagiário. Por isso é que este momento se chama estágio curricular supervisionado.

Mesmo assim, apesar de todas essas preocupações legais e práticas, o

[...] licenciando não vai sair da universidade "tendo aprendido ser professor", ele vai se tornar professor preparado a enfrentar os problemas na sala de aula, a partir da construção de sua práxis, o que pode não acontecer de imediato. É um processo de construção diário que pode levar tempo. (ABREU, 2013, p. 100).

É no ensino médio, também, que o aluno, segundo Callai (1999, p. 64), se apercebe como alguém que contesta, alguém que percebe o lugar, reconhece "[...] nele o que existe e o papel de cada um [...]", embora dificilmente consiga "[...] se reconhecer como ser histórico [...] como sujeito". Em sua pesquisa, Callai constatou que os alunos conside- 
ram mais importante a "[...] Geografia Física, por ser mais objetiva, mais observável, é mais científica e mais interessante que a Geografia Humana, que é muito mais de opiniões, sem objetividade e de imposições de idéias" (1999, p. 65).

A partir de Meinig (2002), é possível, no entanto, contrapor-se à afirmação e levar o olhar também para a geografia humana tendo em vista as Figuras 1 e 2. O autor apresenta a paisagem como: (i) natureza, subordinada pelo homem; (ii) hábitat, natureza retrabalhada e tornada viável ao homem; (iii) artefato, tudo é resultado da ação humana; (iv) sistema, equilíbrio dinâmico de processos interativos; (v) problema, espelho dos malefícios e clamando por mudanças drásticas, na perspectiva da paisagem imaginada, aperfeiçoada pela aplicação da arte e da tecnologia; (vi) riqueza, valor monetário em tudo que vê; (vii) ideologia, contemplar como liberdade, individualismo, competição, utilidade, poder, modernidade, expansão, progresso; (viii) história, cronologia, complexo registro cumulativo do trabalho da natureza e do homem em um dado lugar; (ix) lugar, ambiente, impressões por meio de croqui, fotografia e mapa, visão antiga e fundamental para o geógrafo; e (x) estética, algo próximo à essência, à beleza e à verdade, abstração dissolvida na linguagem da arte pela cor, textura, massa, linha, posição,

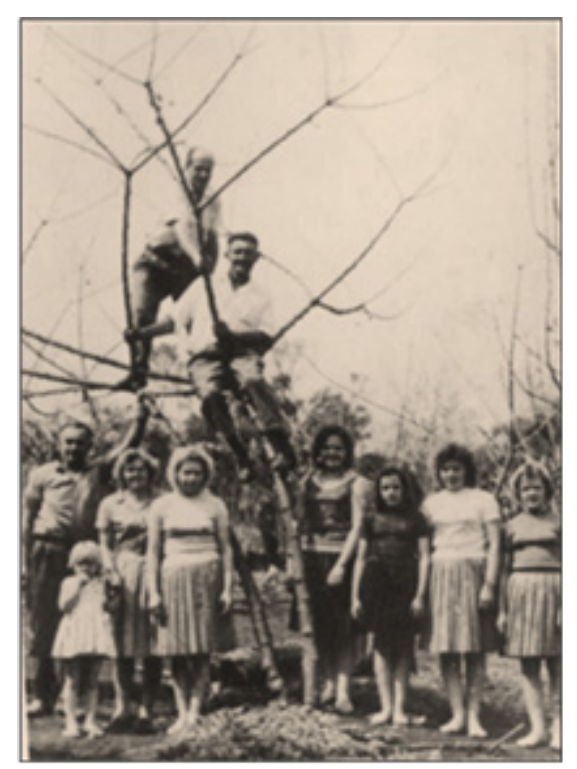

Figura 2: Um pé de mandioca! Uma imagem a ser admirada e registrada, pois para essas famílias era algo incomum. A cena de um pé da mandioca sustentando dois homenssobre seus troncosfoi produzida. Comparar os troncos com os braços das mulheres! Fonte: acervo de Maria Raspe ${ }^{6}$ (1956 e 1957), cedida a Lia Dorotéa Pfluck, 1992.

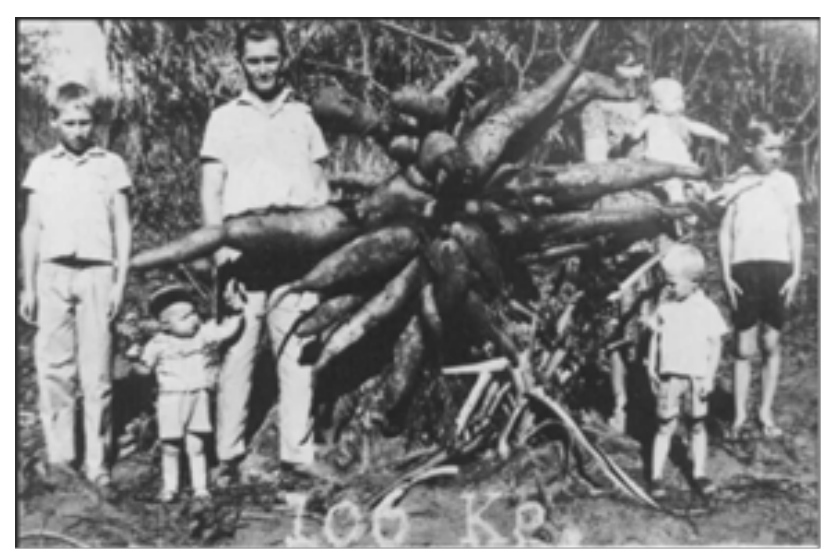

Figura 3: As raízes desse pé de mandioca pesaram $106 \mathrm{~kg}$, inscrito na figura, algo extraordinário.

Fonte: acervo de Maria Raspe ${ }^{6}$ (1956 e 1957), cedida a Lia Dorotéa Pfluck, 1992.

simetria, equilíbrio, tensão (MEINIG, 2002, p. 45). Com isso esse autor dá a entender que também a geografia humana teria alternativas mais científicas a percorrer, além das filosóficas e das artísticas.

As fotografias e o folheto de propaganda (Figuras 1, 2 e 3) que foram levados à sala de aula do $4^{\circ}$ ano do curso de geografia nas aulas de Prática de Ensino em Geografia III/2013 são parte do contexto histórico geográfico do município na década de 1950. Esse período é parte do processo colonizador e da expansão e ocupação da fronteira Oeste do Paraná e do Brasil desencadeada na década de 1930, no governo de Getúlio Vargas, pelo movimento político-intelectual conhecido como "Marcha para o Oeste". É possível perceber, com um olhar mais apurado, que, nas imagens, há algo a mais a ser detectado. Que 'arbusto' é esse que, aparentemente frágil, sustenta dois homens adultos? Na Figura 2 está presente a deformação intencional através da montagem e alteração visual da ordem natural, representada pela posição de homens sobre o pé de mandioca, o que não é normal, pois suas ramas são quebradiças e normalmente não suportam o peso de dois adultos.

O tamanho do pé de mandioca e a espessura de seus troncos, se comparados com a altura das pessoas e aos braços das mulheres, chamam a atenção do observador. Para Kossoy (1989, p. 33), "toda fotografia representa o testemunho de uma criação". O robusto pé de mandioca, para a época, a nada se comparava, em termos de altura e de sua produtividade, com os que os imigrantes conhe- 
ciam dessa planta nas suas terras de origem. No interior de Lajeado/RS, por exemplo, a planta crescia até a altura da cintura de uma pessoa adulta (cerca de $1 \mathrm{~m}$ ), e de produção consideravelmente menor, enquanto essa planta da fotografia ultrapassava os $5 \mathrm{~m}$ de altura e alcançou $106 \mathrm{~kg}$. O pé de mandioca passa a ser o testemunho de uma época de terra fértil e rica em água, onde o filho do agricultor teria um futuro melhor (Figuras 1 e 2). Ocorre, no entanto, que também a fertilidade pode ser testemunha de uma criação de tomar por verdadeiro o que é só aparência (SANTOS, 1988). Em várias oportunidades, os empresários e seus corretores iam à frente dos compradores, abriam uma pequena clareira no mato, faziam um buraco e o enchiam de adubo orgânico (esterco de porco e de gado) trazido do RS e ou de SC, e, em seguida, plantavam alguns grãos de milho ou pedaços de rama de mandioca (conforme a estação do ano), para que se desenvolvessem e servissem de testemunho de que a terra era realmente fértil.

A fotografia pode ser uma 'arma' passível de toda a sorte de 'manipulação', como alerta Kossoy (1989, p. 32):

A fotografia não está, entretanto, enclausurada à condição de registro iconográfico dos cenários, personagens e fatos das mais diversas naturezas a circundar os fotógrafos [...]. A fotografia não pode ser entendida apenas como registro da realidade factual. A deformação intencional dos assuntos através das possibilidades de efeitos [...] montagem e alteração visual da ordem natural das coisas, a criação enfim de novas realidades têm sido exploradas.

De acordo com os relatos de Maria Raspe, as fotografias em questão foram feitas num domingo a pedido dos retratados, por um fotógrafo que passava pelo interior. Os retratados eram vizinhos, três casais e filhas e moravam nas proximidades, e eles não paravam de se orgulhar com o tamanho do pé de mandioca. Era real a imagem. Contou, ainda, que os homens eram brincalhões e logo um aproveitou para escalar e foi seguido do segundo, e, por via das dúvidas, o terceiro simulou estar apoiando o braço esquerdo ao pé de mandioca, no entanto ele estava dando segurança ao que estava em pé no pé de mandioca. Os três homens estavam numa situação de risco e isso não poderia aparecer no registro. $\mathrm{Na}$ Figura 3, os fotografados são outros, uma família com quatro filhos e uma filha de colo, separada pelas raízes do pé de mandioca (Figura 2), que chamaram um fotógrafo para o registro. Questionou-se sobre o porquê da presença das famílias nesses registros? Para Raspe, tratava-se de "programas de domingo" para alguns, sair para conhecer novos vizinhos, ou fazer reconhecimento do lugar, e outros ficavam recolhidos em suas casas pensando naquilo que fora deixado para trás e nas dificuldades que estavam enfrentando. Deve-se considerar que a presença da família confirma também o trabalho agrícola familiar. Na Figura 3 outras pessoas deviam estar próximas da cena ou algum fato fez com que fossem registradas duas direções de olhar, o da mulher e três crianças, diferente do olhar do homem e de uma criança, e a terceira criança se mostra alheia ao registro.

A vestimenta da família da Figura 3 parece mais simples se comparada a da Figura 2, em que as pessoas estão de 'domingueira' (o que confirma a fala de Maria Raspe). Quanto às crianças, as roupas se apresentam curtas, o que pode sugerir que essas crianças cresceram e os pais não tiveram condições de comprar outras. Na Figura 2, tanto os dois homens sobre o pé, como as demais pessoas, estão numa posição preparada para registro fotográfico, uma cena produzida.

Essas imagens fotográficas podem ser confrontadas com citações anteriores, ou seja, ao olhar os pés de mandioca (Figuras 2 e 3 ) e confrontá-los com aqueles que os colonizadores já conheciam, quanta lembrança não pode ser (re) elaborada. Tanto para o colonizador de então como numa análise atual, as figuras passam uma imagem irreal, ainda mais quando dois adultos estão sobre o pé (Figura 2). E, ao se lançar a esperança no visual, criam-se novos sentidos para o lugar. Os sentimentos precisam ser ressignificados ('re-significados'), pois emergem dificuldades, tristezas, saudades substituídas pela realização de que seus filhos teriam uma vida meIhor e de ter terras tituladas, o que representava segurança e direito sobre elas (Figura 1).

Ao mesmo tempo, esses registros não deixam de ser um troféu, pois alguém apertou o botão de uma máquina fotográfica diante de algo extraordinário, e o resto ficou a cargo da publicidade da Maripá. A Maripá, com suas propagandas de divulgação e comercialização da terra promissora, pôde in- 
fluenciar os receptores/ migrantes (SÁNCHEZ, 1999; MAUAD, 1996), terra promissora que "[...] amanhã [será] uma flor da Agricultura Brasileira", remetendo-os ao sucesso e, ao mesmo tempo, à responsabilidade nacional. Para tanto, apresentava, em seu folheto de propaganda: (i) o fácil escoamento dos produtos; (ii) o rio Paraná navegável até São Paulo; (iii) quatro portos fluviais; (iv) terras planas próprias para mecanização; e (v) o "Porto Mendes, com seus grandes armazéns e moderna instalação maquinária para carregamento de navios, construídos pelo governo federal está aguardando tua produção" (Fig. 1). Sobre o Porto Mendes cabem as palavras de Sánchez (1999, p. 80), de que a influência da propaganda será maior quando "[...] o receptor não dispuser da totalidade das ferramentas para sua análise", ou seja, o sulista ou paulista, não conhecendo a região, não saberia que os grandes armazéns e a moderna instalação de maquinaria fora construída nas décadas de 1900/30, abandonada após 1930, portanto obsoleta; que a construção pelo governo federal não confere, pois essas instalações tinham sido construídas pela Compañia de Maderas Del Alto Paraná a partir de 1903.

Assim sendo, essas imagens podem ensinar valores (econômicos e sociais), desmistificar verdades e subjetividades, fazer entender significados e mensagens simbólicas (TONINI, 2003). Se a fotografia mostrasse que 'nas terras férteis de Marechal Cândido Rondon a mandioca crescia feito árvore' (Figura 1), o milho ficava enorme e a espiga mal cabia em uma mão $\nabla$ e 'os peixes, nem se fala, eram do tamanho de um homem!', quem não haveria de acreditar? 'Nas propagandas escritas poderia, eventualmente, constar algum exagero, mas das fotografias, como duvidar' (Figuras 1, 2 e $3^{7}$ ).

\section{FOTOGRAFIA E PROPAGANDA NO ENSINO DE GEOGRAFIA}

As fontes fotográficas e a propaganda são uma possibilidade de investigação e descoberta que promete bons resultados à medida que se tenta sistematizar suas informações, estabelecer métodos adequados de pesquisa e análise para a decifração de seus conteúdos e, por consequência, da realidade que as originou. Com as imagens - fotografias e propaganda - se desenvolveram primeiramente, em sala de aula, na disciplina de Estágio Supervisionado III (Prática de Ensino em Geografia III), de 2013, atividades relacionadas aos seguintes conteúdos programáticos: (i) práticas pedagógicas; (ii) leitura e escrita na geografia; (iii) a formação do professor e as práticas interdisciplinares; (iv) a geografia em nossas práticas cotidianas; (v) recursos didáticos e linguagens no ensino de geografia; (vi) alfabetização cartográfica; e (vii) música, televisão/cinema, teatro, fotografia (Plano de Ensino, 4a série/2013).

Nas aulas de Prática de Ensino de Geografia, as imagens foram distribuídas aos acadêmicos, organizados em grupos de dois a quatro. No caso, tanto as imagens quanto a composição dos grupos foi feita por meio de sorteio. O objetivo proposto foi o de analisar as imagens e relacioná-las a um conteúdo de geografia de ensino médio, preparar uma aula e apresentá-la em sala para os colegas. Os grupos tiveram o tempo de duas aulas para o planejamento e produção da aula (conteúdo X imagens), organização da apresentação e ainda outras duas aulas para análise e elaboração do material. E, nas aulas seguintes, realizou-se a apresentação com duração máxima de 20 minutos por grupo, seguida de 10 minutos para arguições por parte dos colegas, complementações e novas sugestões de exploração das imagens relacionadas ao conteúdo escolhido pelo grupo.

Essas atividades foram desenvolvidas com os seguintes objetivos: (i) estimular e ampliar o debate teórico-metodológico enquanto processo qualificador do licenciado diante das diferentes concepções, conceitos, métodos e instrumentos de produção do Ensino de Geografia; (ii) produzir, analisar e operacionalizar atividades teóricas e práticas, contemplando o processo do ensino-aprendizagem em Geografia a partir de categorias concretas e abstratas; e (iii) promover discussões em torno da elaboração de planejamentos e da previsão de situações didáticas considerando as atividades voltadas para o manuseio de recursos e uso de linguagens didáticas aplicadas ao ensino de Geografia no Ensino Médio.

Para tanto, os acadêmicos foram divididos em grupos e orientados a desenvolver uma aula para ensino médio contendo plano de aula, objetivos claros, desenvolvimento do conteúdo, experiências e ou práticas, e avaliação, a partir do recurso didático 
da imagem - fotografias ou propaganda (Figuras 1 e 2). Para a avaliação deveria ser considerada a compreensão e o entendimento dos alunos quanto ao conteúdo, à proposta, ao uso da metodologia e ao material utilizado em relação ao ensino médio.

No ensino médio, um dos objetivos da Geografia "[...] é a organização de conteúdos que permitam ao aluno realizar aprendizagens significativas. [...] [considerando] os conhecimentos prévios do aluno e o meio geográfico no qual ele está inserido" (OCEMs, 2006, p. 44). A partir das análises das imagens, os acadêmicos relacionaram-nas aos conteúdos aplicáveis ao ensino médio, para isso consultando livros didáticos, as OCEMs e os PCNs. De acordo com as Orientações Curriculares do Ensino Médio, emitidas pelo MEC (OCEMs, 2006, p. 50):

Os conceitos cartográficos (escala, legenda, alfabeto cartográfico) e os geográficos (localização, natureza, sociedade, paisagem, região, território e lugar) podem ser perfeitamente construídos a partir das práticas cotidianas. [...] incluindo as categorias espaço e tempo. [...] admitir a diversidade de fontes e de linguagens [...]. Essas linguagens (cartográfica, textual, corporal e cênica, iconográfica e oral) servirão de apoio para as aulas de Geografia.

Os conceitos analisados em sala de aula foram e podem embasados em Carlos (1996), Casseti (2002), Cavalcanti (2002), Corrêa (2003), Cunha (2008), Kaercher (2004), Pontuschka et al. (2007) Santos e Chiapetti (2011) e Thiesen (2011). A relação dos conceitos e a aplicação às imagens e a seus elementos foram:

- Espaço e Tempo: consideram-se as condições e as formas de apropriação do espaço específico do Oeste do Paraná, por exemplo; espaços-tempos que se interpenetram e onde ocorrem desencontros de perspectivas; e aonde imigrantes chegaram e se instalaram, definindo e redefinindo espaços e lugares.

- Sociedade: consideram-se as relações sociais e culturais permeadas pelo poder da empresa colonizadora Maripá e a própria apropriação e organização do espaço geográfico em suas diferentes manifestações (território, região, lugar, etc.) pelos agora titulados dessas terras.

- Lugar: considera-se a manifestação dos grupos sociais e das pessoas em relação à noção e ao sentimento de pertencimento a esse território - onde seus filhos poderão ter um futuro melhor; lugar em que se desenvolvem relações sociais e econômicas e se cria uma identidade.

A proposta da aula foi desenvolvida seguida de discussões abertas, relatando experiências pessoais e aplicações desenvolvidas ou possíveis de serem desenvolvidas durante as aulas de regência do estágio supervisionado nas escolas públicas. A relação do ensinar, aprender e aprofundar os conceitos geográficos foi/é possível fazendo um paralelo destes com os eixos temáticos, como se apresenta a seguir (Quadro 1). E, as imagens e seus elementos (Figuras 1, 2 e 3) permearam da seguinte forma os

Quadro 1: Conceitos geográficos e eixos temáticos: um paralelo

\begin{tabular}{|c|l|}
\hline Conceitos & \multicolumn{1}{c|}{ Eixos temáticos } \\
\hline $\begin{array}{c}\text { Espaço e tempo } \\
\text { Sociedade } \\
\text { Lugar }\end{array}$ & $\begin{array}{l}\text { Formação territorial brasileira, articulada ao processo da Marcha para o Oeste, do } \\
\text { movimentos migratórios ao longo do Oeste brasileiro. }\end{array}$ \\
\hline $\begin{array}{c}\text { Sociedade } \\
\text { Lugar }\end{array}$ & $\begin{array}{l}\text { O espaço agrário e a manutenção das estruturas agrárias tradicionais como forma } \\
\text { de resistência ou necessidade, dependendo da época de análise. }\end{array}$ \\
\hline $\begin{array}{c}\text { Espaço e tempo } \\
\text { Sociedade }\end{array}$ & $\begin{array}{l}\text { Organização e distribuição da população, os movimentos migratórios sulistas } \\
\text { desde a década de 1930 e a formação de novas identidades territoriais. }\end{array}$ \\
\hline $\begin{array}{c}\text { Espaço e tempo } \\
\text { Sociedade } \\
\text { Lugar }\end{array}$ & As diferentes fronteiras e a organização da geografia política no Oeste do Paraná, \\
estado e organização do território regional e nacional.
\end{tabular}

Fonte: organizado pela autora com base em OCEM (2006, p. 56-60) 
Quadro 2: Imagens e eixos temáticos

\begin{tabular}{|c|c|}
\hline Imagens & Eixos temáticos \\
\hline $\begin{array}{l}\text { Fig. 1: Chamando para Toledo, na Fazenda Britânia, no Estado } \\
\text { do Paraná; que oferece garantia de uma terra legal e escritura } \\
\text { imediata ao comprador; as terras são planas e apropriadas para } \\
\text { lavoura mecanizada; Toledo com apenas } 3 \text { anos de existência é } \\
\text { paróquia, tem colégio, médicos, hospital, farmácia, indústria, } \\
\text { comércio, cinema. }\end{array}$ & $\begin{array}{l}\text { Formação territorial brasileira, } \\
\text { articulada ao processo da Mar - } \\
\text { cha para o Oeste, dos movimen - } \\
\text { tos migratórios ao longo do Oeste } \\
\text { brasileiro. }\end{array}$ \\
\hline $\begin{array}{l}\text { Fig. 1: Terras planas e apropriadas para lavoura mecanizada; o } \\
\text { mato de espécies de madeira de lei prova a fertilidade do solo; } \\
\text { preços parcelados; a Fazenda Britânia amanhã será uma "flôr" } \\
\text { da Agricultura Brasileira. Fig. } 2 \text { e 3: Agricultura familiar, famílias, } \\
\text { destaques rurais como programas de domingo. }\end{array}$ & $\begin{array}{ll}\text { O espaço agrário e a manuten } & - \\
\text { ção das estruturas agrárias tra } & - \\
\text { dicionais como forma de resis } & - \\
\text { tência ou necessidade, depen } & - \\
\text { dendo da época de análise. }\end{array}$ \\
\hline $\begin{array}{l}\text { Fig. 1: Sede da Maripá em Porto Alegre (RS) e filial em Toledo; } \\
\text { passagem de Concórdia (SC) a Toledo com desconto ou gratuita } \\
\text { conforme a quantidade de colônias compradas, vendas em ljuí, } \\
\text { Santo Ângelo e Cruz Alta (RS); todos esses desejos o Senhor } \\
\text { encontra reunidos em Toledo na Fazenda Britânia, no Estado do } \\
\text { Paraná. Fig. } 2 \text { e 3: famílias em torno de destaques rurais como } \\
\text { programas de domingo. }\end{array}$ & \begin{tabular}{|l|} 
Organização e distribuição da \\
população, os movimentos mi - \\
gratórios sulistas desde a déca - \\
da de 1930 e a formação de no - \\
vas identidades territoriais.
\end{tabular} \\
\hline $\begin{array}{l}\text { Fig. 1: Apresenta a fronteira entre o Oeste do Paraná com o } \\
\text { Paraguai através do Rio Paraná e seus diversos portos fluviais; } \\
\text { a terra livre de morros, pedras e formigas, de fácil escoamento } \\
\text { dos produtos; estradas de rodagem; ferrovia, armazéns. }\end{array}$ & $\begin{array}{l}\text { Diferentes fronteiras e a organi - } \\
\text { zação da geografia política no } \\
\text { Oeste do PR, do estado e do } \\
\text { território regional e nacional. }\end{array}$ \\
\hline $\begin{array}{l}\text { Fig. 1: Espécies de madeira de lei provam a fertilidade do solo; } \\
\text { terra livre de morros, pedras, formigas e rica em água, clima } \\
\text { saudável; terras planas e apropriadas para lavoura mecanizada; } \\
\text { hoje o paraíso dos caçadores e amanhã "flôr" da Agricultura } \\
\text { Brasileira. Fig. } 2 \text { e } 3 \text { : mato cedeu lugar à lavoura de mandioca } \\
\text { (por ex.), para o sustento da família; derrubada da mata em } \\
\text { terras planas e apropriadas para lavoura mecanizada massiva } \\
\text { da floresta para a agroindústria. }\end{array}$ & $\begin{array}{l}\text { As questões ambientais, sociais } \\
\text { e econômicas resultantes dos } \\
\text { processos de apropriação dos } \\
\text { recursos naturais em diferentes } \\
\text { escalas. }\end{array}$ \\
\hline $\begin{array}{l}\text { Fig. 1: Terra fértil; terras planas e apropriadas para lavoura } \\
\text { mecanizada; hoje o paraíso dos caçadores e amanhã "flô" da } \\
\text { Agricultura Brasileira; Rio Paraná navegável do Sul até São Paut } \\
\text { lo; indicação de ferrovia e } 4 \text { portos fluviais; } 285 \text { km de estradas } \\
\text { de rodagem; facilidade de escoamento dos produtos; armazéns } \\
\text { e maquinaria para carregamento de navios. Fig. } 2 \text { e 3: produção } \\
\text { incomparável de mandioca (por ex.). }\end{array}$ & $\begin{array}{l}\text { Produção e organização do es - } \\
\text { paço geográfico e mudanças nas } \\
\text { relações de trabalho (técnicas e } \\
\text { tecnológicas substituem as tradi- } \\
\text { cionais); novas geografias; dinâ - } \\
\text { mica econômica mundial; e redes } \\
\text { de comunicação e informações. }\end{array}$ \\
\hline
\end{tabular}

Fonte: organizado pela autora.

eixos temáticos (Quadro 2). Com as imagens - linguagens ou recursos didáticos - se pode desbravar o mundo para além da sala de aula (TRAVASSOS, 2001), e elas podem ser uma poderosa ferramenta de auxílio no ensino de Geografia para trabalhar temas e conceitos (SANTOS e CHIAPETTI, 2011).

Como professor de Geografia, pode-se proporcionar práticas e reflexões que levem os alunos à compreensão da realidade com práticas cotidianas, à leitura da vivência do lugar e à construção do conhecimento de professor e de aluno, por meio de fotografias e de propagandas do período da coIonização do município, por exemplo, ocorrida na década de 1950, no Oeste do Paraná.

\section{CONSIDERAÇÕES}

De forma geral, a atividade foi tida como satisfatória. Os alunos relacionaram as imagens de então com propagandas de vendas de produtos 
comuns na mídia atual. A maior dificuldade foi o tempo de fala para a apresentação dos grupos e para a complementação por parte dos colegas, em função de poderem relacionar fatos espaciais locais com temas nacionais. Essa atividade tornou-se também proveitosa por ampliar o debate teóricometodológico a partir de diferentes concepções, conceitos, métodos e linguagens geográficas; pela operacionalização de atividades teóricas e práticas, contemplando o processo do ensino-aprendizagem em geografia a partir de categorias concretas e abstratas; e confecção de planejamentos, situações didáticas aplicadas ao ensino médio (plano de aula, objetivos claros, desenvolvimento do conteúdo, experiências e ou práticas, avaliação, a partir de um recurso didático - fotografias ou propaganda).

Dessa forma foi possível alcançar itens de aprendizagem significativos com os conhecimentos prévios dos alunos (imagens analisadas) e do meio geográfico no qual eles estão inseridos (município e oeste do Paraná) e transitar por conteúdos aplicáveis ao ensino médio.

Neste artigo buscou-se refletir sobre a importância do uso de imagens no ensino médio de geografia. Ainda que $80 \%$ das páginas de livros didáticos de geografia possam conter algum tipo de imagem (TONINI, 2003), essas imagens ainda são utilizadas como simples ilustrações dos textos verbais e ocupam papel secundário no processo de ensino-aprendizagem. Cabe, porém, ao professor realizar um planejamento para definir o melhor momento de incorporar imagens e associá-las aos conhecimentos do conteúdo. Essas linguagens podem, de fato, servir como apoio para as aulas de geografia e potencializar a análise e o conhecimento do espaço geográfico.

Trabalhar com fotografias e propaganda serviu para mostrar que é possível desenvolver uma aula utilizando imagens da década de 1950, de um determinado município, relacionando-as aos conceitos e aos eixos temáticos no ensino médio de geografia, como o que foi aplicado na disciplina de Estágio Supervisionado III (Prática de Ensino em Geografia III). Independentemente das opções metodológicas e diante da dinâmica da sociedade, os conceitos geográficos devem ser considerados e podem proporcionar ao aluno condições para ler o mundo.
Há, no entanto, de se considerar que as fotografias e a propaganda podem refletir, ainda que sutilmente ou subjetivamente, outras questões para as quais professor e alunos devem voltar sua atenção. Assim, por exemplo, para os espectadores daquele momento da fotografia (os fotografados), o pé de mandioca - 'o evento' - pode ter 'acontecido' independentemente de sua apreciação, mas também pode ter sido resultado de um cenário produzido, preparado pela empresa colonizadora. Por exemplo, atente-se para o seguinte cenário: no lugar do pé de mandioca existia grande quantidade de matéria orgânica in situ, uma área recém-desmatada, somado a um balde de adubo (esterco) e, nessa condição, se planta a rama. Assim, cresce um vigoroso 'arbusto', um pé de mandioca capaz de sustentar dois homens! Para esse cenário, para esse lugar, afluem pessoas, famílias que desenvolveram o sentimento de pertencimento, tomando aquela terra como a sua terra dos sonhos e das realizações. Em condições normais de solo, uma rama de mandioca, após um ano de plantio, fornece raízes para consumo doméstico e, com dois anos, pode ser usado, também, para consumo dos animais (porcos e gado). Diferentemente, porém, pelo porte desse pé da planta (Figura 2), é possível deduzir que as condições de solo foram produzidas e que o pé de mandioca poderia ter de quatro a cinco anos de plantio, pois o registro fotográfico é de 1956 e as derrubadas da floresta começaram em 1950. As famílias fotografadas moravam nas proximidades de dois a três anos.

De tudo isso se poderia deduzir que fora criado um cenário de lugar e sociedade permeada de relações de poder, de 'verdades' produzidas, de subjetividades, para justificar que todos os desejos do agricultor estão reunidos na Fazenda Britânia, no Estado do Paraná. Nesse contexto, as fotografias e a propaganda não deixam de ser meios de comunicação, meios regidos pelo capital, que conduz o jogo para justificar o que circulava na propaganda (Figura 1), entendimento que, para Chauí (2006), é a produção de simulacros pelo poder ideológico-político. É, portanto, necessário estabelecer metodologia adequada de pesquisa e de análise para a decifração de seus conteúdos e, por consequência, da realidade que os originou, ainda que essa realidade seja um simulacro, como escrevera Kossoy (1989). 
Enfim, a fotografia e a propaganda, com seus inúmeros encantos, significados complexos, subjetivos e concretos, ou pelos seus simulacros, são imagens que abrem um universo de possibilidades geográficas a serem trabalhadas e relacionadas ao dia a dia do professor e dos alunos. Trabalhar com esse universo de possibilidades significa tornar o ensino mais prazeroso, promover o 'pensar sobre', desvendar e desenvolver a capacidade de contextualizar, estabelecer relações e conferir significado às informações e às comunicações. Como resultado final, os dois quadros acima representam a síntese da relação desenvolvida entre conceitos, eixos temáticos e imagens apresentadas em sala de aula como parte prática da disciplina de Prática de Ensino III.

$O$ processo de ensino-aprendizagem com o uso de imagens dependerá, indubitavelmente, da iniciativa de cada professor-leitor. Quanto às imagens, entre o sujeito que olha ou lê e a imagem elaborada há muito mais que os olhos podem ver (ou que os ouvidos podem ouvir). Então, simplesmente, depois de apertar o botão, na educação, não se pode deixar o resto por conta do poder!

\section{REFERÊNCIAS BIBLIOGRÁFICAS}

ABREU, Silvana. O estágio supervisionado na formação do Professor de Geografia: diálogos ininterruptos. In: ALBUQUERQUE, M. A. M. de; FERREIRA, J. A. de S. (Orgs.). Formação, pesquisa e práticas docentes: reformas curriculares em questão. João Pessoa-PB: Mídia, 2013. p. 87-104.

AGUIAR, Marcio M. de; ANTONELLO, I. T. A natureza da produção do conhecimento geográfico no Ensino Médio. In: CALVENTE, M. del C. M. H.; ARCHELA, R. S.; GRATÃO, L. H. B. (Org.). Múltiplas geografias: ensino, pesquisa, reflexão. Londrina-PR: Edições Humanidades, 2007. p. 47-76 (Volume IV).

ASARI, Alice Y.; ANTONELLO, I. T.; TSUKAMOTO, R. Y. (Org.). Múltiplas geografias: ensino - pesquisa - reflexão. Londrina-PR: Edições Humanidades, 2004.

BARTHES, Roland. A Mensagem fotográfica. In: LIMA, Luís Costa (Org.). Teoria da cultura de massa. Rio de Janeiro-RJ: Paz e terra, 1978.
BRASIL. Ministério da Educação. Conselho Nacional de Educação. Parecer CNE/ CP 28/2001. Nova redação ao Parecer CNE/CP 21/2001, ... Formação de Professores da Educação Básica, em nível superior, curso de licenciatura, de graduação plena. Disponível em: <http://portal.mec.gov.br/cne/index>. Acesso em: 12 out. 2013.

BRASIL. Ministério da Educação. Conselho Nacional de Educação. Parecer CNE/ CP 009/2001: Diretrizes Curriculares Nacionais para a Formação de Professores da Educação Básica, em nível superior, curso de Licenciatura, de graduação plena. Disponível em: $<$ http://portal.mec.gov.br/cne/index>. Acesso em: 12 out. 2013.

CALLAI, Helena Copetti. A geografia no ensino médio. Terra Livre, no 14. São Paulo-SP: AGB, p. 60-99, jan./jun. 1999.

CARLOS, Ana Fani Alessandri. O lugar no/do mundo. São Paulo-SP: Hucitec, 1996.

CASSETI, Valter. A natureza e o espaço geográfico. In: MENDONÇA, F.; KOZEL, S. (Orgs.). Elementos de epistemologia da geografia contemporânea. Curitiba -PR: Ed. da UFPR, 2002.

CAVALCANTI, Lana de Souza. Geografia e práticas de ensino. Goiânia-GO: Alternativa, 2002.

CHAUÍ, Marilena. Simulacro e poder. São Paulo-SP: Ed. Fund. Perseu Abramo, 2006. p. 5-78.

CORRÊA, Roberto L. Espaço, um conceito chave de Geografia. In: CASTRO, I. E.; GOMES, P. C. da C.; CORRÊA, R. L. (Org.). Geografia - conceitos e temas. Rio de Janeiro-RJ: Bertrand Brasil, 2003.

CUNHA, Maria Isabel da. Os conceitos de espaço, lugar e território nos processos analíticos da formação dos docentes universitários. Revista Educação UNISINOS, v. 12, no 3 . São Leopoldo-RS: Editora Unisinos, set./dez. 2008.

GREGORY, Valdir. Fronteiras, migrações e imaginários. In: VANDERLINDE, T. (Org.). Fronteiras: impactos socioambientais na terra prometida. Porto Alegre -RS: Evangraf, 2011. p. 17-28. 
IPARDES. Fundação Édison Vieira. O Paraná reinventado: política e governo. Curitiba-PR, 1989.

KAERCHER, Nestor André. Quando a geografia crítica pode ser um pastel de vento. Mercator Revista de Geografia da UFC. Ano 03, número 06. Fortaleza-CE, 2004.

KENSKI, Vani Moreira. O ensino e os recursos didáticos em uma sociedade cheia de tecnologias. In: $D i-$ dática: o ensino e suas relações. Campinas-SP: Papirus, 1996 (Coleção Magistério: Formação e Trabalho Pedagógico).

KOSSOY, Boris. Fotografia e história. São Paulo: Ática, 1989.

LEÃO, Vicente de Paula; LEÃO, Inês de Carvalho. Ensino de geografia e mídia: linguagens e práticas pedagógicas. Belo Horizonte-MG: Argumentum, 2008.

LUCENA, Célia R. P. de Toledo. Memórias de famílias migrantes: imagens do lugar de origem. Revista Projeto História. São Paulo-SP: EDUC, n. 17/11/ 1998.

MACCARI, Neiva Salete Kern. Migração e memórias: a colonização do oeste paranaense. Dissertação (Mestrado em História). Curso de Pós-Graduação em História, Universidade Federal do Paraná. Curitiba-PR, 1999.

MALUF, Marina. Ruídos da memória. São Paulo-SP: Siciliano, 1995.

MARTINS, Eliane Rosa. A imagem no livro didático: um estudo sobre a didatização da imagem visual. Dissertação (Mestrado em Educação), Faculdade de Educação, Universidade Federal de Minas Gerais, Belo Horizonte-MG, 2002.

MAUAD, Ana Maria. Através da imagem: fotografia e história-interfaces. Tempo. Rio de Janeiro-RJ, vol. 1, n 2, 1996, p. 73-98. In: <www.historia.uff.br/tempo/ artigos _dossie/artg2-4.pdf®>. Acesso em: 13 abr. 2014. p. 1-15.

MEINIG, Donald W. O olhar que observa: dez versões da mesma coisa. Espaço e Cultura, n. 13. UERJ: Rio de Janeiro-RJ, p. 35-46, jan./jun. 2002.

MUSSOI, Arno B. A fotografia como recurso didático no ensino de geografia. Artigo apresentado ao Programa de Desenvolvimento Educacional do Paraná (PDE), convênio SEED e Unicentro-PR, 2008. In: <http://www.diaadiaeducacao.pr.gov. $\mathrm{br} /$ portals/pde/arquivos/785-2.pdf>. Acesso em: mar. 2014.

NASCIMENTO, Dalvana B. do. RESENHA. FILIZOLA, Roberto \& KOZEL, Salete. Teoria e prática do ensino de Geografia: memórias da terra. São Paulo: FTD, 2009. Revista Brasileira de Educação Geográfica, Campinas-SP. v. 3, n. 5, p. 161-165, jan./jun. 2013.

OCEMs. Orientações curriculares para o ensino médio. Ciências humanas e suas tecnologias. v. 3. BrasíliaDF: Ministério da Educação, Secretaria de Educação Básica, 2006.

OLIVEIRA JR, Wenceslao M. de. Fotos em sites: geografias da cultura contemporânea. Geografares, n. 7, p. 9-21. Vitória-ES, 2009.

PCNs. DOSSIÊ: Os PCNs em discussão. Terra Livre, $\mathrm{n}^{\circ}$ 13, São Paulo-SP: AGB, 1997.

PFLUCK, Lia Dorotéa. Impactos e riscos ambientais numa terra prometida. In: VANDERLINDE, Tarcísio (Org.). Fronteiras: impactos socioambientais na terá prometida. Porto Alegre-RS: Evangraf, 2011. p. 97110.

PFLUCK, Lia Dorotéa. Marechal Cândido Rondon: o município pela geografia e pela História. Porto Alegre-RS: Evangraf, 2013.

PLANO DE ENSINO. ANEXO II - Resolução $n .^{\circ}$ 282/2006 - CEPE. Unioeste. Centro de Ciências Humanas, Educação e Letras. Campus de Marechal Cândido Rondon-PR. Curso de Geografia. Disciplina Estágio Supervisionado III (Prática de Ensino III), 4ª Série, 2013.

POLLAK, Michael. Memória e identidade social. Estudos Históricos, Rio de Janeiro-RJ. v. 5, n. 10, p. 200212, 1992. 
PONTUSCHKA, Nídia; PAGANELLI, Tomoko; CACETE, Núria Hanglei. Para ensinar e aprender geografia. São Paulo-SP: Cortez, 2007.

SÁNCHEZ, FranciscoMartinez. Os meios de comunicação. In: Ministério da Educação. Medianamente! Televisão, cultura e educação. Brasília-DF, 1999.

SANTOS, Milton. A metamorfose do espaço habitado: fundamentos teóricos e metodológicos da geografia. São Paulo-SP: Editora Hucitec, 1988.

SANTOS, Rita de C.E. dos; CHIAPETTI, Rita J. N. Uma investigação sobre o uso das diversas linguagens no ensino de Geografia: uma interface teoria e prática. Geografia Ensino \& Pesquisa, v. 15, n 3, p. 167-184. Santa Maria-RS, set./dez. 2011.

SILVA, Oscar; MACIEL, C. F. Toledo e sua história. Toledo-PR: Prefeitura Municipal, 1988.

SOARES, Maria Lucia de Amorim. De semióforos, motivo edênico e ensino de geografia. Geografia, Londrina-PR. v. 10, n², p. 129-133, jul./dez. 2001.

SPOSITO, Eliseu S. A escola e o ensino de geografia: elementos para uma discussão. Revista Faz Ciência, v. 1, no 1. Francisco Beltrão-PR: FACIBEL, p. 9-18, 1997.

THIESEN, Juares da Silva. Geografia escolar: dos conceitos essenciais às formas de abordagem no ensino. Geografia Ensino \& Pesquisa, v. 15, no 1, p. 83-94. Santa Maria-RS, jan./abr. 2011.

THOMPSON, Paul. A voz do passado: história oral.Rio de Janeiro-RJ: Paz e Terra, 1992.

TONINI, Ivaine Maria. Imagens nos livros didáticos de geografia: seus ensinamentos, sua pedagogia... Mercator, UFC, ano 2, no 04, p. 35-43. Fortaleza-CE, 2003.

TRAVASSOS, Luiz E. P. A fotografia como instrumento de auxílio no ensino da Geografia. Revista de Biologia e Ciências da Terra, v. 1, nº 2, João Pessoa-PB, 2001. Disponível em: <http://eduep.uepb.edu.br/ $\mathrm{rbct} / \mathrm{sumarios} / \mathrm{pdf} /$ fotografia.pdf $>$. Acesso em: 15 maio 2014.

\section{Notas de Fim:}

1- Os outros recursos foram letras de músicas, pedaço de trilho de trem, cadeira, etc., que serão analisados em outro momento.

2- Os exploradores de erva-mate do início do século XX no Oeste do Paraná entraram em decadência com a Segunda Guerra Mundial. E assim, na década de 1940 fundou-se a Industrial Madeireira Colonizadora Rio Paraná S/A - Maripá, que adquiriu, em 1946, a Fazenda Britânia, da Compañia de Maderas Del Alto Paraná (de capital argentino e inglês). Ver, também, Silva (1988).

3- A terra era parcelada em pequenas propriedades, 24 ha (colônias), 2,5 ha (chácaras) e 500 a $800 \mathrm{~m}^{2}$ (lotes urbanos) possibilitava a compra pelo imigrante. Tratava-se de povoamento estratégico, pois atendia à efetivava ocupação da fronteira do Oeste do Paraná, propaganda, sucesso de venda e valorização das terras da empresa Maripá (PFLUCK, 2009).

4- O sujeito "Eles" se refere aos representantes da Maripá e seus corretores (vendedores).

5- "Bons e maus elementos, atraídos os primeiros pela fama da fertilidade das terras roxas paranaenses, e os segundos, pela facilidade dos negócios, deixaram os rincões de origem em São Paulo e Minas Gerais e vieram, juntamente com muitos aventureiros, apossar-se abruptamente das melhores terras devolutas do Estado, assentando benfeitorias provisórias; desordenadamente, a mais das vezes, em terras já tituladas ou comprometidas". Essas foram afirmações de Moisés Lupion, então governador do Estado do Paraná (IPARDES, 1989, p. 33).

6- Maria Raspe imigrou para Curvado, interior do município, em 1954. Em 1992, Raspe emprestou as fotografias à autora quando se realizava o Projeto de História Viva (entrevista com os colonizadores do município, década de 1950).

7- Além das fotografias aqui utilizadas, outras faziam parte da divulgação das terras da Maripá, como as de carroçadas de miIho, de porcos (com mais de $150 \mathrm{~kg}$ ), de peixes do Rio Paraná (com mais de $60 \mathrm{~kg}$ ), conforme Pfluck (2009).

\section{Correspondência da autora:}

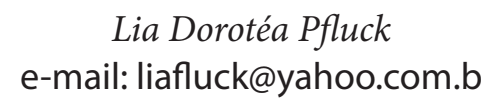

Artigo recebido em: 01/04/2015

Aceito para publicação em: 09/11/2015 